Знання, 1997, - 224 с. 4. Выготский Л. С. Психология искусства / Л. С. Выготский. М. : Просвещение, $1968,-365$ с. 5. Гончаренко Н. В. Художественное в эстетике и в искусстве / Н. В. Гончаренко. - К. : Радянська школа, 1990. - 249 с. б. Каган М. С. О месте искусства в жизни школы / М. С. Каган // Искусство в школе. - 1992. - № 1. С. 11-19. 7. Крутецкий П. А. Эстетическое воспитание / П. А. Крутецкий. - М. : Знание, 1987 - 234 с. 8. Кушаев П. А. Основы эстетического воспитания / П. А. Кушаев. - М. : Педагогика, 1985. - 250 с. 9. Лисенко В. Особливості ціннісної структури підростаючої особистості/В. Лисенко// Цінності освіти і виховання: [наук.-метод. зб.]/ за ред. О. Сухомлинської. - К., 1997. - 224 с. 10. Львова Ю. Л. Развивать дар творчества / Ю. Л. Львова. - К. : Искусство, 1987. 136 с. 11. Мясищев В. М. Психология отношений: Избраные психологические труды / В. М. Мясищев; (под ред. Бодалева А. А) - М. : МОДЕК МПСИ, 2004. - 664 с. 12. Половникова П. Б. Эстетические чуства / П. Б. Половникова. - К. : Знание, 1978 343 с. 13. Полянова І. Шляхи удосконалення виховання // Наук. записки ТДПУ. Сер. Педагогіка. - 1999. - № 2.-С. 15-20. 14. Эстетика: [учеб. пособие]/ под ред. Е. В. Колесниковой, В. А. Лозового (отв. ред.), Н. Г. Чибисовой. - Сумы : Университет. книга, 1999. - 304 с.

Ганна Давиденко

\title{
КОНЦЕПТУАЛЬНІ ОСНОВИ ІНКЛЮЗИВНОЇ ОСВІТНЬОЇ ПАРАДИГМИ
}

Давиденко Г. В. Концептуальні основи інклюзивної освітньої парадигми.

Статтю присвячено дослідженню концептуальних основ інклюзії. Визначено та науково обгрунтуванню філософські засади інклюзивної освіти: нова гуманітарна соціальна модель інвалідності, принцип включення, принцип відкритої невизначеної особистості, концепція «нормалізації», принцип еволюційності й тотальних реформ на всіх рівнях суспільства.

Ключові слова: інклюзія, соціальна модель інвалідності, спеціальна освіта, інтеграція, інклюзивна освіта.

Давыденко А. В. Концептуальные основы инклюзивной образовательной парадигмы.

Статья посвящена исследованию концептуальных основ инклюзии. Определены и научно обоснованы философские принципы инклюзивного образования: новая гуманитарная социальная модель инвалидности, принцип включения, принцип открытой неопределенной личности, концепция «нормализации», принцип эволюционности и тотальных реформ на всех уровнях общества.

Ключевые слова: инклюзия, социальная модель инвалидности, специальное образование, интеграция, инклюзивное образование.

Davydenko H. V. Conceptual foundations of inclusive educational paradigm.

The article deals with a research of conceptual bases of inclusion. Such philosophical principles of inclusive education as a new humanitarian social model of disability, a principle of including, a principle of an open indefinite personality, a concept "normalization", a principle of evolution and total reforms at all levels of society have been defined and scientifically grounded.

Key words: inclusion, social model of disability, special education, integration, 
inclusive education.

У нових життєвих умовах базовим принципом освіти є іï широка доступність. Нині принцип доступності освіти дорівняно до одного із основних прав людини. Якісна освіта передбачає задоволення особливих освітніх потреб кожного індивіда, в тому числі й для осіб з обмеженими можливостями, без відриву такої особи від звичного соціального оточення, сім’ї, друзів.

Питання забезпечення можливості доступу людей з інвалідністю до освітнього середовища висвітлено у працях вітчизняних та зарубіжних науковців, зокрема, О. Безпалько, В. Ільїна, А. Колупаєвої, Є. Мартинова, О. Мовчан, О. Полякової, Т. Самсонова, Н. Софій, О. Столяренко, В. Синьова, П. Таланчука, Є. Тарасенка, Н. Шаповала, А. Шевцова, Ф. Амстронг, Н. Борисової, Б. Барбера, Г. Беккера, П. Бурдьє, Дж. Девіса, К. Дженкса, Х. Кербо, М. Крозьє, Ф. Кросбі, П. Романова, В. Шмідт, К. Тейлора, О. Ярської-Смірнової та ін. Однак, незважаючи на велику кількість публікацій та монографічних праць у царині інклюзивної освіти, окремі аспекти її імплементації потребують детального вивчення. До них належить і питання концептуальних основ інклюзивного навчання.

Mema cmammi- визначити та науково обгрунтувати філософські засади інклюзивної освіти: нову гуманітарну соціальну модель інвалідності, принцип включення, принцип відкритої невизначеної особистості, концепцію «нормалізації», принцип еволюційності й тотальних реформ на всіх рівнях суспільства.

Нові філософські концепції освіти пов'язані із трансформацією соціальної парадигми інвалідності у другій половині XX ст. Як зазначає А. Колупаєва, «В передових країнах Західної Свропи, починаючи з 70-х років відбувалася перебудова спеціальної освіти. Зокрема, інтегроване та інклюзивне навчання дітей 3 особливостями розвитку визначено як основну форму здобуття освіти неповносправними» [4].

В основу філософії інклюзивної освіти покладено соціальну модель інвалідності, яка претендує на нову гуманітарну концепцію прав, свобод і можливостей людини [7; $10 ; 11 ; 12 ; 13]$. Її головне завдання - подолання стереотипів застарілої медичної моделі інвалідності, згідно з якою людина, що має особливі потреби розглядається як «хворий». Як зазначає Н. Артюшенко, медична модель передбачає, що людина 3 особливостями розвитку - хворий, який є об'єктом жалощів, благочинності й узагалі тягар для суспільства, яка потребує постійного догляду й лікування: «Дитина 3 інвалідністю - це проблема, він сприймається суспільством виключно через призму порушень в розвитку. Від дітей з інвалідністю в рамках медичної моделі очікується пристосування до укладеного середовища й суспільства» [1, с. 13-14].

Соціальна модель інвалідності передбачає розв'язання двох проблем. По-перше, подолання соціальних стереотипів відчуженості, дисоціологізації з боку оточення, які вважаються більшим бар'єром, аніж самі особливі потреби; по-друге, визнання дитини-інваліда повноцінним індивідом, в якого, як і в інших дітей, є свої переваги (здібності, інтереси) і який має право не тільки відвідувати навчальні заклади на рівні 3 іншими, а й бути сприйнятим суспільством таким, яким він $є$. Інклюзивна філософія передбачає розв'язання дуалістичної проблеми, яка постала в давній інтегративній моделі, коли дитина-інвалід імплантувалася в суспільство на особливих правах (спецзаклади, особливий статус). Дуалізм між специфікою неповносправної дитини і iii повноцінним включенням в суспільство розв'язується шляхом соціального й педагогічного узгодження полюсів: дитина, з одного боку, є повноцінним членом суспільства, тобто нічим не виокремлюється серед інших, з другого, - iіi індивідуальна 
специфіка розглядається як будь-яка інша особистісна відмінність, яка $є$ не перешкодою, а навпаки - педагогічним ресурсом, що може бути використаний у позитивному сенсі.

Філософські засади інклюзивної освіти мають у своїй основі сучасні педагогічні, юридичні (правові) й гуманітарні концепції, пов'язані з новою парадигмою реалізації людини в суспільстві. Трансформаційні процеси, які наразі відбуваються в усіх сферах людської діяльності зумовлюють феномен «вирівнювання» прав, свобод і можливостей людей, які від природи або внаслідок життєвих перипетій набули специфічного статусу, який обмежує їхні природні фізичні або когнітивні здібності.

Основним положенням філософським інклюзивної освіти є принцип включення, за яким дитина, що має специфічні потреби, реалізовує своє право на освіту в середовищі повноцінного навчального колективу, позитивний вплив якого сприяє, 3 одного боку, повноцінному набуттю знань, умінь і навичок, 3 іншого, - сприяє соціалізації й «згладжуванню» комплексів і симптомів відокремленості, неповноцінності та відірваності від життєвого середовища.

Метою інклюзії є уникнення соціальної сегрегації, яка стосується не тільки інвалідності й інших типів психо-фізичної обмеженості людини, а й ії відмінностей в соціальному класі, культурі, расі, національності, релігії тощо [9].

Одна 3 цілей інклюзії $\epsilon$ максимальна ліквідація розмежувань «повноцінна дитина - неповноцінна дитина». Це можливо за умов реалізації супровідного процесу інтеграції в освіті: «Інклюзивна освіта передбачає не тільки активне включення й участь дітей та підлітків з обмеженими можливостями в освітньому процесі звичайної школи, але більшою мірою перебудову всього процесу масової освіти як системи для забезпечення освітніх потреб всіх дітей» [5].

У центрі інклюзивної освітньої парадигми лежить принцип відкритої невизначеної особистості, яка сприймає зовнішні умови свого життєустрою не як низку бар'єрів, а як низку можливостей. За таких умов людина починає усвідомлювати себе абсолютним суб'єктом свого життя, а світ - як відкриту систему, зорієнтовану і на іiі специфічні потреби: «Моделлю особистості в новій парадигмі інклюзивної освіти має стати інноваційна людина. Вона розглядає навколишній світ не як сталу, гармонійну структуру, до якої потрібно пристосовуватися, а як сферу пізнавальної та практичної невизначеності, яку потрібно редукувати як послідовність різноманітних труднощів, що необхідно подолати» [2, с. 27].

Іншим принципом інклюзивної освіти є концепція «нормалізації», в основі якої положення про необхідність максимального наближення людей 3 особливими потребами до способу й режиму, прийнятого у громаді. Це положення знайшло відображення в міжнародних правових документах, згідно з якими необхідно всіляко уникати стереотипів меншовартості й неповноцінності стосовно людей з особливими потребами. Як зазначає О. Броварська, «Декларація ООН про права розумововідсталих $\epsilon$ першим нормативно-правовим документом щодо визнання осіб 3 порушеннями психофізичного розвитку суспільно повноцінною в соціальному сенсі меншиною, яка потребує соціального та правового захисту» [2, с. 28].

Наступним принципом інклюзії є модернізація самої системи освіти. Вона передбачає заміну старих жорстких й адаптивно «закритих» форм організації навчання до нових, за яких школа або вищий навчальний заклад беруть на себе відповідальність за інтеграцію людини 3 особливими потребами в колектив. Ю. Волчелюк указує, що «інклюзивна освіта вимагає подальшої модернізації вищої педагогічної освіти та системи підвищення кваліфікації педагогічних кадрів, що передбачає: 
- забезпечення спеціальної підготовки і перепідготовки педагогічних кадрів для роботи з студентами $з$ обмеженими фізичними можливостями в умовах інклюзивного освітнього простору;

- забезпечення спеціальної підготовки консультантів 3 питань навчання та розвитку осіб з обмеженими фізичними можливостями в умовах інклюзивного освітнього простору;

- запровадження системної організаційно-методичної, консультативнороз'яснювальної роботи серед керівників навчальних закладів, громадськості, батьків щодо забезпечення права людей 3 обмеженими фізичними можливостями на освіту» [3, с. 48-51].

Важливим принципом інклюзивної освіти $є$ iї еволюційна й реформістська світоглядна природа, яка виявилася в останні десятиліття в численних громадянських рухах, прийнятті всесвітніх декларацій, що свідчить про динаміку розвитку концепції гуманності, життєвості й рівноправності. Так, в 1990 році в місті Джомтьєн (Таїланд) відбулася Всесвітня конференція 3 освіти для всіх, яка визначила нові перспективи освіти як важливої соціальної надбудови. Право на освіту кожної людини у ній окреслено як невід'ємне й доступне, а й якісне, таке, що в новому часі потребує розширення сфери впливу, партнерських стосунків, нових освітніх стандартів, співпраці держави, школи й сім’ї. У 1994 році прийнято знакову Саламанську декларацію (Іспанія), філософським лейтмотивом якої стали повага й поціновування різноманітності й індивідуальності людської особистості, що інтерпретує неповносправність як форму індивідуального вияву людської природи [9].

Нова концепція знайшла своє продовження на Всесвітньому форумі з освіти в Дакарі (2000 року), де основним філософським підгрунтям стали не тільки освіта й виховання для усіх, а і прогрес і новітні цілі освітнього процесу для людей всіх рас, релігій і націй незалежно від стану здоров’я [6].

Інклюзивна парадигма в рамках загальної демократичної трансформації суспільства передбачає всеосяжний і багаторівневий підхід, який торкатиметься змін в політичній, соціальній та економічній структурі суспільства. На економічному рівні це має реалізуватися в новій системі фінансування освіти, підвищенні повноважень шкіл та вищих навчальних закладів, у політичній - в розробленні відповідної законодавчої бази й соціальної політики, у соціальному - у широкій палітрі реформ від зміни стереотипів і неповносправності- до рівної участі й забезпеченні усіх членів суспільства.

Як зазначає І. Россіхіна, філософія інклюзії невідривна від застарілої концепції ексклюзії, яку необхідно подолати: «На наш погляд, необхідно погодитись 3 тим, що соціальне виключення виникає внаслідок численних порушень підсистем суспільства, а отже, соціальна інклюзія теж має бути багатовимірною. Серед аспектів (напрямів, заходів) соціальної інклюзії в цих соціальних підсистемах треба виокремити політично-правові (можливість реалізації своїх прав та інтересів), соціальноекономічні (викорінення бідності, наявність достойно оплачуваної роботи, якісного житла й комунальних послуг), культурні (доступна і якісна освіта, включеність в культурне життя суспільтва) тощо [8, с. 18].

Отже, інклюзія - це нова філософія не тільки освітньої галузі, а й системи суспільства в цілому, яке, зважаючи на його сучасну високотехнологічну й інформаційну структуру, може і має забезпечити повноцінну участь усіх членів незалежно від їхніх можливостей у соціальному й культурному житті, комунікативному діалозі й усебічній реалізованості. 
Філософія інклюзивності будується на низці принципів, серед яких найголовніші - нова гуманітарна соціальна модель інвалідності, принцип включення, принцип відкритої невизначеної особистості, концепція «нормалізації», принцип еволюційності й тотальних реформ на всіх рівнях суспільства. Це передбачає поступову перебудову всієї системи людських стосунків на мікро- (сім'я, колектив) та макрорівні (соціальна група, держава), упровадження політичних, соціальних та економічних реформ в сучасному демократичному й гуманістичному руслі.

Перспективи подальших наукових пошуків убачаємо у висвітленні питань, пов'язаних із нормативними основами, на яких вибудовується інклюзивне навчання в системі вищої освіти країн Європейського Союзу.

\section{Література}

1. Артюшенко Н. П. Организационно-педагогические условия обучения детей с ограниченными возможностями здоровья средствами инклюзивного образования : автореф. дисс. на соискание науч. степени канд. пед. наук : спец. 13.00.01 «Общая педагогика, история педагогики и образования» / Н. П. Артюшенко. - Томск, 2010. 23 с. 2. Броварська О. А. Філософські аспекти інклюзивної освіти / О. А. Броварська // Соціально-педагогічна робота в закладах освіти інклюзивної орієнтації : тези доповідей VIII Всеукраїнської науково-практичної конференції.Хмельницький: Хмельницький інститут соціальних технологій Університету «Україна», 2013. - С. 27-30. 3. Волчелюк Ю. І. Організація навчання для студентів 3 обмеженими фізичними можливостями в інклюзивному освітньому просторі / Ю. І. Волчелюк // Соціально-педагогічна робота в закладах освіти інклюзивної орієнтації: тези доповідей VIII Всеукраїнської науково-практичної конференції.Хмельницький: Хмельницький інститут соціальних технологій Університету «Україна», 2013. - С. 48-51. 4. Колупасва А. А. Досвід реалізації інклюзивної освіти в країнах Європи / [Електронний ресурс]: Режим доступу: http://www.ussf.kiev.ua/index.php?go=Inklus\&id=16

5. Назарова Н. М. Интегрированное (инклюзивное) образование: генезис и проблемы внедрения [Электронный ресурс]: Режим доступа: Интернет конференция: Современные дети какие они? 6. Развитие инклюзивного образования: сборник материалов/ сост. Ю. Б. Симонова, С. А. Прушинский. - М. : Региональная общественная организация Перспектива. - М. : 2007. - 48 с. 7. Романов П. В Политика инвалидности. Проблемы доступной среды и возможности занятости / П. В. Романов, Е. Р. Ярская-Смирнова // Социологические исследования. - 2005. - № 2. - С. 44-55. 8. Россихина И. Г. Социальная инклюзия студентов как функция учреждения среднего профессионального образования : автореф. дисс. на соискание науч. степени канд. соц. наук : спец. 22.00 .04 «Социальная структура, социальные институты и процессы» / И. Г. Россихина. - Новочеркасск, 2010. - 23 с. 9. Саламанская декларация и рамки действий по образованию лиц с особыми потребностями, принятые Всемирной конференцией по образованию лиц с особыми потребностями: доступ и качество, Саламанки, Испания, 7-10 июня 1994 года. [Электронный ресурс]: Режим доступа: http://www.un.org/russian/dokument/declarat/ salamanka.pdf. 10. Скок Н. И. Биосоциальный потенциал лиц с ограниченными возможностями и социальные механизмы его регуляции // Социологические исследования. - 2005. - № 4. - С. 124 127. 11. Трудоустройство инвалидов: интегрированный подход [Электронный pecypc].- Режим доступа: http// www/socpolitika/ ru/rus/social_policy_reserch 1349/ dokument $360 / \mathrm{shtml}$. 12. Ферапонтова О. И. Социальные аспекты инклюзивного образования детей-инвалидов // Вестник СамГУ. - 2007. - № 1 (51) - С. 165-171. 13. Ярская В. Н. Инклюзия - новый код социального равенства // Образование для 
всех: политика и практика инклюзии: сборник научных статей и научно-методических материалов. - Саратов: Научная книга, 2008. - 445 с.

УДК377.3.015.311

Ольга Сюсова

\title{
УСТАНОВЛЕННЯ ВИМОГ ДО ОСОБИСТІСНИХ ЯКОСТЕЙ КВАЛІФІКОВАНОГО РОБІТНИКА
}

\author{
Єжова О. В. Установлення вимог до особистісних якостей кваліфікованого \\ робітника.
}

Робота спрямована на встановлення науково обгрунтованого переліку індивідуальних особливостей особистості, необхідних для успішного набуття професійних компетенцій робітників-швейників. Установлено, що представникам усіх досліджуваних професій потрібні якості типу «людина-техніка», а для деяких завдань - «людина-людина» та «людина-художній образ». Створений перелік охоплює 39 професійно важливих якостей особистості, у результаті апріорного ранжування список скорочений до 33-х.

Ключові слова: професійно важливі якості, швачка, кравець, закрійник, оператор швацького устаткування.

Ежова О. В. Установление требований к личностным качествам квалифицированного рабочего.

Работа направлена на установление научно обоснованного перечня индивидуальных особенностей личности, необходимых для успешного формирования профессиональных компетенций рабочих-швейников. Установлено, что представителям всех исследуемых профессий необходимы качества типа «человектехника», а для некоторых заданий - «человек-человек» и «человек-художественный образ». Созданный перечень включает 39 профессионально важных качеств, в результате априорного ранжирования список сокращен до 33-х.

Ключевые слова: профессионально важные качества, швея, портной, закройщик, оператор швейного оборудования.

Yezhova O. V. Setting out requirements for the personality qualities of a skilled worker.

The article is aimed at establishing a scientifically substantiated list of personality traits necessary for the successful forming professional competences of garment workers. The author determined that people of these occupations require such qualities as «person-totechnique» and for some tasks - «person-to-person» and «person-to-artistic image». This list includes 39 professionally important qualities; the list was reduced to 33 qualities as a result of a priori ranking.

Key words: professionally important qualities, seamstress, tailor, tailor's cutter, sewing equipment handler.

Успіх професійної діяльності значною мірою залежить від відповідності обраної професії та індивідуальних якостей працівника. Характер та ступінь розвиненості професійно важливих якостей зумовлюють, в числі інших чинників, професійну надійність працівника. У зв'язку з цим актуальним є завдання встановлення науково обгрунтованого переліку індивідуальних особливостей особистості, необхідних для 